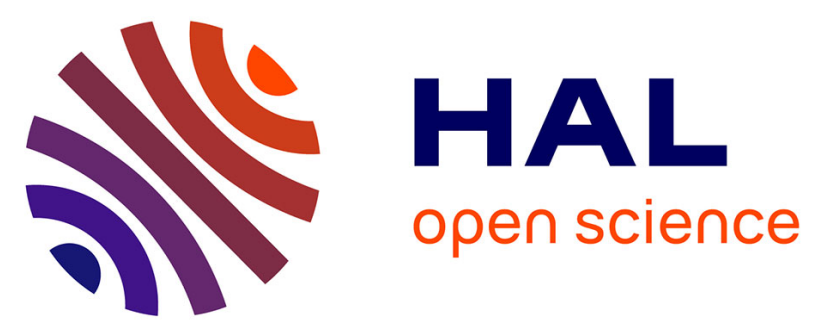

\title{
Modelling and simulation of a doubly fed induction generator in stand alone variable speed hydro turbine
}

D. Ramuz, Mamadou Bailo Camara, Martine Sébéloué, Ollivier Tamarin, F. Roubaud, H. Clergeot, J.-M. Kauffmann

\section{- To cite this version:}

D. Ramuz, Mamadou Baïlo Camara, Martine Sébéloué, Ollivier Tamarin, F. Roubaud, et al.. Modelling and simulation of a doubly fed induction generator in stand alone variable speed hydro turbine. 2005 IEEE 11th European Conference on Power Electronics and Applications, Sep 2005, Dresden, Germany. 10 pp.-P.10, 10.1109/epe.2005.219777 . hal-03005794

\section{HAL Id: hal-03005794 \\ https://hal.science/hal-03005794}

Submitted on 14 Nov 2020

HAL is a multi-disciplinary open access archive for the deposit and dissemination of scientific research documents, whether they are published or not. The documents may come from teaching and research institutions in France or abroad, or from public or private research centers.
L'archive ouverte pluridisciplinaire HAL, est destinée au dépôt et à la diffusion de documents scientifiques de niveau recherche, publiés ou non, émanant des établissements d'enseignement et de recherche français ou étrangers, des laboratoires publics ou privés.

\section{(c)(1)}

Distributed under a Creative Commons Attribution| 4.0 International License 
See discussions, stats, and author profiles for this publication at: https://www.researchgate.net/publication/224643148

\section{Modelling and simulation of a doubly fed induction generator in stand alone variable speed hydro turbine}

Conference Paper · January 2005

DOI: 10.1109/EPE.2005.219777 · Source: IEEE Xplore

CITATIONS

10

7 authors, including:

M.B. Camara

Université du Havre

113 PUBLICATIONS 1,754 CITATIONS

SEE PROFILE

(25)

Ollivier Tamarin

Université de Guyane / Université de Bordeaux

31 PUBLICATIONS 161 CITATIONS

SEE PROFILE

Some of the authors of this publication are also working on these related projects:

Multi-source Energy Management View project

Project These Intitul View project
READS

270

Martine Sebeloue

Institut Universitaire de Technologie (IUT) de Kourou

4 PUBLICATIONS 12 CITATIONS

SEE PROFILE 


\title{
Modelling and Simulation of a Doubly Fed Induction Generator in stand alone Variable Speed Hydro Turbine
}

\author{
D. RAMUZ*( (еPE Member), M. CAMARA**, M. Sebeloue*, O. TAMarin*, \\ F. Roubaud*, H. Clergeot*, J-M. KaUfFMANN** \\ *Groupe de Recherche sur les Energies Renouvelables (GRER - French Guiana) \\ IUT de Kourou - BP 725 - 97387 Kourou (France / FWI) \\ : (+33) 0594328002 / Fax : (+33) 0594328175 \\ @:denis.ramuz@guyane.univ-ag.fr, henri.clergeot@guvane.univ-ag.fr \\ 品 : http://www.univ-ag.fr/recherche.htm \\ ** Laboratoire d'Electronique, Electrotechnique et Systèmes (UTBM/L2ES - Belfort) \\ Parc Technologique - 90010 Belfort (France) \\ 표 : (+33) 0384583601 / Fax : (+33) 0384583636 \\ @: jean-marie.kauffmann@univ-fcomte.fr

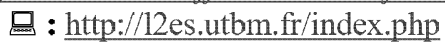

Abstract: In this paper, the authors propose an approach with problems of electricity production in isolated sites in French Guiana. Indeed, the geographical context of French Guiana implies a concentration of the population on the littoral connected to the electrical national grid "EDF"(I), whereas population living in rural areas and in majority located at the edge of the rivers, are dedicated to their own means of production by using Power Diesel Generators or Photovoltaic systems.

Keywords: Doubly Fed Induction Generator (DFIG), Vector Control Strategy, Stand alone ${ }^{2}$, Variable Speed Hydro Turbine, Renewable Energy systems

\section{1 - Introduction}

In the case of the production by Micro-Hydro Power Station ${ }^{3}$ with variable speed turbines, a Doubly Fed Induction Generator (DFIG) can optimize the power produced. Indeed, due to the speeds and the flows variability of the French Guiana rivers, DFIG makes it possible to compensate the variability in acceptable proportions and guarantees a good energy quality in the network. A strategy of vector control provides constant voltage, frequency, and this, in spite of the speed variations at driving shaft and of reasonable variations of power consumption; moreover, it will allow a hybridization with other power electricity production plants (as secondary producer by interconnection) of several electricity production systems or as principal producer via a common Direct Current bus.

On the basis of a recent prototype [ 3 ], a sufficient torque to supply a turbine up to $500 \mathrm{~kW}$ could be obtained from a flow of water of $1 \mathrm{~m} . \mathrm{s}-1$ with a very weak water fall. To avoid tides influence, the hydropower plant is located at more than 30 to $50 \mathrm{~km}$ from the littoral. Thus, this solution very well adapted in French Guiana where water falls are weak can also be used in other countries with the same specificities like Benin, Guinea or other countries in equatorial Africa.

A DFIG needs for magnetizing an auxiliary source, which feeds the windings at the rotor. The originality of this work is to use a DC source obtained through photovoltaic cells.

\footnotetext{
${ }^{1}$ EDF: Electricité de France

${ }^{2}$ Autonomous system $=$ stand alone $=$ isolated grid

${ }^{3}$ Micro-Hydro Power Station : $P<150 \mathrm{kVA}$
} 


\section{2 - Characterization and modelling of the elements of a Hydraulic Turbine in French Guiana [1]}

\section{1 - Hydraulic characterization of some rivers}

The approach suggested for an hydraulic turbine can be compared with that done in a traditional way for a wind turbine : the variability of the primary source as well as the dimensioning of the unit can be of the same order of complexity.

For that, annual hydrological statements (experimental results) of the principal rivers (IRD(4) Guyana) given on figure 1 hereafter, initially enable us to characterize the flows and the possible variations of the primary source of energy. To support these data over longer durations, figure 2 hereafter gives us a statement over 47 years (IRD-Guyana) of some principal rivers. Indeed, the conditions of measurements of these statements were justified by hydraulic considerations and logistics all while keeping any disturbing influence as much as possible (non turbulent conditions of flow, no influence of the tides...).

\begin{tabular}{|c|c|c|c|c|c|c|c|c|}
\hline Fleuve / rivière & Stations & $\begin{array}{c}\text { débit } \\
\text { moyen } \\
\left(\mathrm{m}^{3} / \mathrm{s}\right)\end{array}$ & $\begin{array}{c}\text { surface } \\
\left(\mathrm{km}^{*}\right)\end{array}$ & $\begin{array}{c}\text { débit } \\
\text { spéćfique } \\
\left(/ / \mathrm{s} / \mathrm{km}^{2}\right)\end{array}$ & $\begin{array}{c}\text { nombre } \\
\text { d'années } \\
\text { de } \\
\text { mesures }\end{array}$ & $\begin{array}{c}\text { maximum } \\
\text { mensuel } \\
\left(\mathrm{m}^{3} / \mathrm{s}\right)\end{array}$ & $\begin{array}{c}\text { minimum } \\
\text { mensuel } \\
\left(\mathrm{m}^{3} / \mathrm{s}\right)\end{array}$ & $\begin{array}{l}\text { écart type } \\
\left(\mathrm{m}^{3} / \mathrm{s}\right)\end{array}$ \\
\hline Maroni & Langa tabiki & 1681,3 & 60940 & 27,6 & 47 & 5450 & 54,20 & 1241 \\
\hline Oyapock & Saut Maripa & 838,5 & 25100 & 33,4 & 44 & 2970 & 67,10 & 585 \\
\hline Lawa & Maripasoula & 742,4 & 28300 & 26,2 & 44 & 2800 & 21,30 & 564 \\
\hline Oyapock & Camopi & 531,6 & 5920 & 89,8 & 23 & 1610 & 37,60 & 366 \\
\hline Alitani & Antécume Pata & 356,1 & 10300 & 34,6 & 30 & 1160 & 56,10 & 232 \\
\hline Mana & Saut Sabbal & 311,3 & 10300 & 30,2 & 32 & 1300 & 23,80 & 196 \\
\hline Approuague & Saut Athanase & 303,6 & 7520 & 40,3 & 8 & 676 & 74,20 & 145 \\
\hline Sinnamary & Pefti Saut & 243,3 & 5900 & 41,2 & 31 & 848 & 48,10 & 128 \\
\hline Approuague & Pierrette & 234,7 & 6200 & 37,9 & 35 & 738 & 51,50 & 131 \\
\hline Tampock & Dégrad Roche & 163 & 7650 & 21,3 & 45 & 700 & 2,11 & 143 \\
\hline Comté & Saut Bief & 101 & 1760 & 57,4 & 30 & 417 & 13,40 & 65,9 \\
\hline Karouabo (1) & Karouabo & 5,44 & 80 & 65,3 & 10 & 17,8 & 0 & 5,13 \\
\hline
\end{tabular}

Figure 1: Annual hydrological statement in various measuring sites carried out by IRD - Cayenne

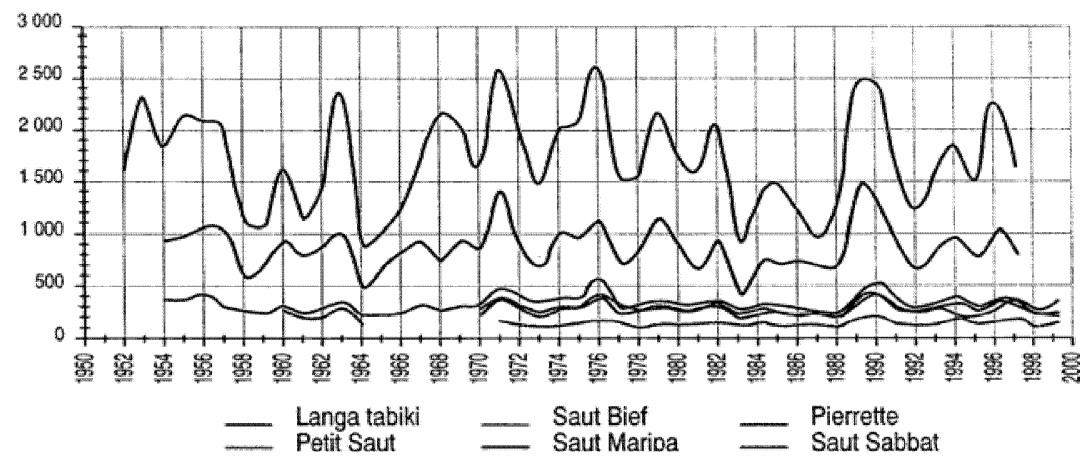

Figure 2: Hydrological statement over 47 years in some measuring sites carried out by l'IRD ${ }^{4}$ - Cayenne

According to the statement of figure 1, we can note that at the various hydrological stations, the medium flows can fluctuate in an average ratio going from 1 to 3 (see even more). Moreover, the annual statements (figure 1) are very fluctuating but it is also the case during the 47 years (figure 2). No phenomenon of cycle can be highlighted (these flows could be a little bit linearized by installation

${ }^{4}$ IRD : Institut de Recherche pour le Développement 
of tanks before the turbines). Moreover, we can note significant medium flows under low drop heights (some meters).

Thus, these experimental statements enable us to better characterize the flows of some principal rivers, and will make it possible to make a certain choice of the unit turbine - generator. Initially, the choice will be carried out by a compromise between the maximum exploitation of the flows with an output of energy conversion as highest as possible and this with the minimum of civil engineering.

\section{2 - Mathematical modelling of a possible water turbine:}

The approach suggested by the turbine Banki (or Crossflow, Ossberger) was neglected by large manufacturers because of his output slightly lower (efficiency $\geq 80 \%$ ) than that of a Francis turbine much better and more spread, but its advantage is the simplicity of its construction. This turbine is appropriate for ranges of flows going from $20 \%$ to $100 \%$ and for falls varying from 1 to $200 \mathrm{~m}$. Moreover, figure 3 shows us a comparison between various turbines and this, according to the fall height and specific speed; figure 4 gives the output of such a turbine according to the flow and the used portion (compared with a Francis turbine). In figure 5 a comparison is made between the different type of turbines according to the fall height, flow and possible power.

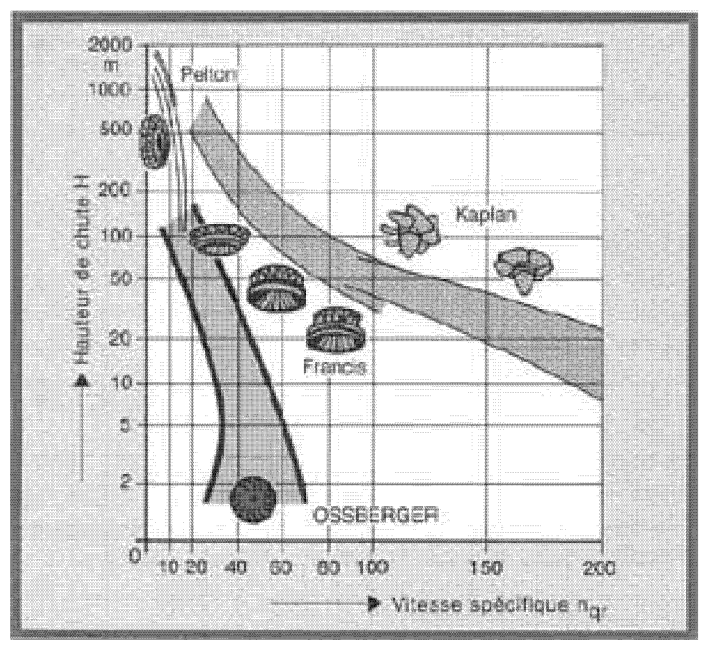

Figure 3: Comparison between various turbines according to specific the speed and drop height (m) (Ossberger)

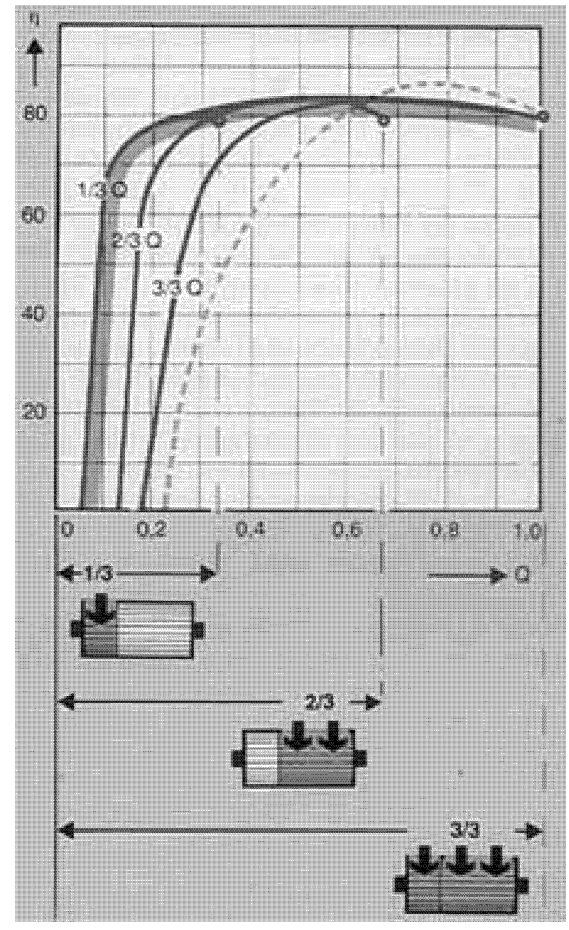

Figure 4: Output of the turbine according to the efficiency and the flow compared with a Francis turbine

Thus, the previous figures 3,4 and 5 enabled us to characterize the choice of the type of turbine according to the fall height $\mathrm{H}(\mathrm{m})$, the flow $\mathrm{Q}(\mathrm{m} 3 / \mathrm{s})$, the output of a Banki turbine and of the possible power $(\mathrm{kW})$. The inherent characteristic of a Banki turbine (Ossberger) given on figure 4, highlights a constant value for the efficiency $(\sim 80 \%)$ according to the used portion of the turbine (itself function of the $\mathrm{Q}$ flow) compared with a Francis turbine.

So, a Banki turbine could be a good choice due to its flexibility of operation on a broad range speed and its suitable output and efficiency. Moreover, taking into account the height of the waterfalls ( 1 to $3 \mathrm{~m}$ as average value) and low velocity of the rivers $(\sim 1 \mathrm{~m} / \mathrm{s})$, the speed of the turbine will be rather slow. 


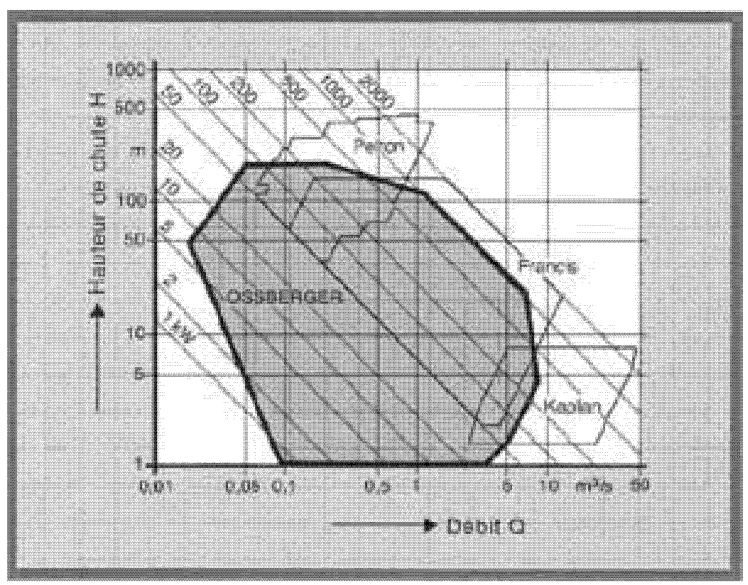

Figure 5: Operation range of various turbines according to the possible Power $(\mathrm{kW})$, flow $(\mathrm{m} 3 / \mathrm{s})$, and fall height $(\mathrm{m})$ (Ossberger)

A current and very much used in hydraulics formula is given by:

$$
V=\lambda * \sqrt{2 * g * H}
$$

in which: $\mathrm{V}$ the speed $(\mathrm{m} / \mathrm{s}), \lambda$ a loss ratio $(\sim 0,95 \ldots 1)$, g acceleration of gravity (Paris) and $\mathrm{H}$ the fall height $(\mathrm{m})$ without considering pressure losses.

Moreover, the possible power can be calculated by:

$$
P=\eta * \rho^{*} g * Q^{*} H
$$

in which, $\mathrm{P}$ is the power $(\mathrm{kW}), \eta$ the global efficiency (turbine, multiplier, generator, transformer, lines, control, ...), $\rho$ density (water $\sim 1000 \mathrm{~kg} / \mathrm{m} 3)$, Q the flow $(\mathrm{m} 3 / \mathrm{s}$ )

The Torque according to the flow, radius and tangential speed is given by Euler equation

$$
C_{m}=Q * \frac{\varpi}{g} *\left(r_{0} v_{t 0}-r_{1} v_{t 1}\right)
$$

with:

$C_{m}:$ torque $(\mathrm{Nm})$

$\varpi=\rho^{*} g:$ density weight of water $(\mathrm{N} / \mathrm{m} 3)$

$r_{0}:$ radius of water filament input $(\mathrm{m})$

$v_{t 0}:$ water filament tangential speed $(\mathrm{m} / \mathrm{s})$

$r_{1}$ and $v_{t 1}:$ output wheel radius

The output power $P_{m}$ of the turbine, which runs with a speed $\omega(\mathrm{rd} / \mathrm{s})$ who is expressed by: $P_{m}=C_{m} * \omega$

In the case of a Banki turbine, the actual values often differ from those calculated because of pressure losses existing in the conduits or the diversion channels resulting from the term $\mathrm{H}$. 
Concerning the solar sunning needed by the photovoltaic cells to magnetize the rotor windings, it was measured sunning power of about 5 to $7 \mathrm{kWh} / \mathrm{m}^{2} /$ day and $2200 \mathrm{~h}$ of annual average insulation in French Guiana (Météo France).

\section{3 - Modelling of the doubled fed asynchronous machine used as autonomous generator in hybridization with a photovoltaic system}

In the case of the production by Hydraulic turbine (2), the Doubly Fed Induction Generator (DFIG) makes it possible to optimize the produced power. Indeed, considering the variable speeds and flows of the French Guiana rivers, the Doubly Fed Induction Generator (DFIG), allows to compensate these variations in acceptable proportions while guaranteeing a good quality of the electrical network. The strategy of operation and control consists in providing constant voltage $V$ and frequency $\mathrm{f}$ and this, in spite of the speed variations and reasonable consumption variations. Moreover, hybridization on DC bus by a photovoltaic system allows the magnetizing of the machine $(\mathrm{V}, \mathrm{f}$ regulation). Photovoltaic system may also contribute to active and reactive power regulation.

The scientific Matlab/Simulink ${ }^{\mathrm{TM}}$ software will be used for simulation. A DSPACE system is used for data acquisition and for the control laws on an experimental test bench equipped with a 10 $\mathrm{kW}$ asynchronous machine.

\subsection{1 - General diagram}

The Doubly Fed Induction Generator (DFIG) will be used in stand alone operation. In this configuration, a converter MLI with IGBT will control the rotor. Moreover, the originality of this system is conferred by a hybridization on Bus DC of an already existing photovoltaic system (as indicated in figure 6 below) which will make it possible to ensure the magnetizing of the machine.

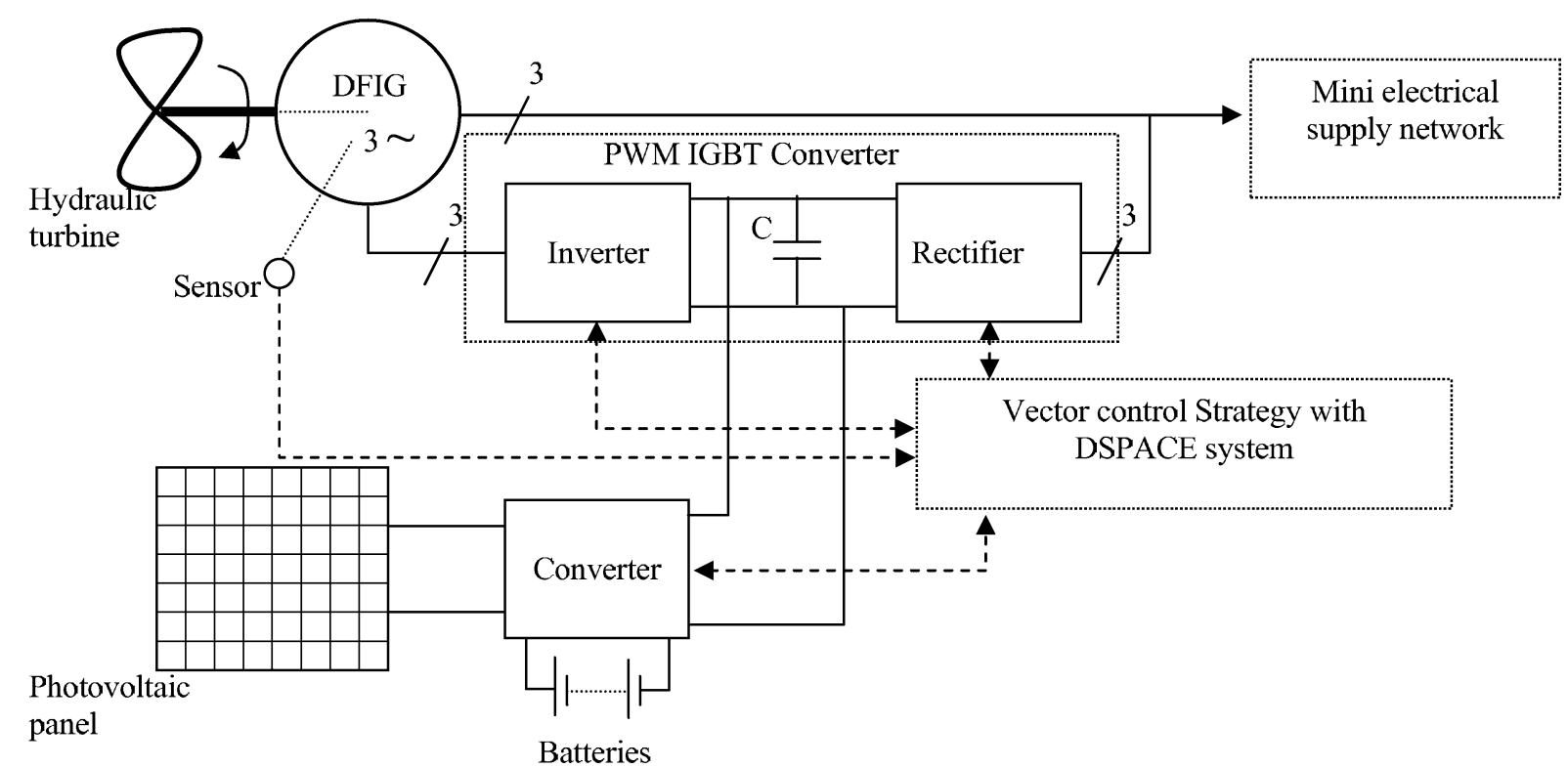

Figure 6: Asynchronous machine with wound rotor used as generator linked with a photovoltaic system on a DC Bus. 
The system is composed of a three-phase asynchronous machine with wound rotor actuated at variable speed ( $+/-30 \%$ compared to nominal speed) like a traditional generator and of a converter feeding the rotor which at any moment provides the complement of frequency necessary to maintain constant the frequency in the stator.

\subsection{2 - Modelling of the machine}

- Dynamic model of the doubly fed induction generator

A commonly used model for the Doubly Fed Generator is the Park model (with the assumptions of using). Indeed, under these conditions, the asynchronous machine can be described by a differential equations system in $\mathrm{d}$, q components; $\theta_{\mathrm{k}}$ is an unspecified angle with fixed axes related to the stator as indicated in figure 7.

Thus, the equations of the machine are:

$$
\underline{\mathrm{V}}_{\mathrm{s}}{ }^{\mathrm{k}}=\mathrm{R}_{\mathrm{s}} \underline{\underline{I}}^{\mathrm{k}}{ }^{\mathrm{k}}+\frac{\mathrm{d} \underline{\Phi}_{\mathrm{s}}{ }^{\mathrm{k}}}{\mathrm{dt}}+\mathrm{j} \omega_{\mathrm{k}} \underline{\Phi}_{\mathrm{s}}{ }^{\mathrm{k}}
$$

$$
\underline{\mathrm{V}}_{\mathrm{r}}{ }^{\mathrm{k}}=\mathrm{R}_{\mathrm{r}} \underline{\mathrm{I}}_{\mathrm{r}}{ }^{\mathrm{k}}+\frac{\mathrm{d} \underline{\Phi}_{\mathrm{r}}{ }^{\mathrm{k}}}{\mathrm{dt}}+\mathrm{j}\left(\omega_{\mathrm{k}}-\omega\right) \underline{\Phi}_{\mathrm{r}}{ }^{\mathrm{k}}
$$

with: $\omega_{\mathrm{k}}=\frac{\mathrm{d} \theta_{\mathrm{k}}}{\mathrm{dt}}$ angular velocity of the axes system $(\mathrm{d}, \mathrm{q})$ and $\omega$ angular velocity of the rotor compared to the stator; $\mathrm{R}_{\mathrm{S}}$ and $\mathrm{R}_{\mathrm{r}}$ are respectively the stator and rotor resistance)

$$
\text { Equations of flux are: } \begin{aligned}
& \underline{\Phi}_{\mathrm{s}}{ }^{\mathrm{k}}=\mathrm{L}_{\mathrm{s}} \underline{\mathrm{I}}_{\mathrm{s}}{ }^{\mathrm{k}}+\mathrm{MI}_{\mathrm{r}}{ }^{\mathrm{k}} \\
& \underline{\Phi}_{\mathrm{r}}{ }^{\mathrm{k}}=\mathrm{L}_{\mathrm{r}} \underline{\mathrm{I}}_{\mathrm{r}}{ }^{\mathrm{k}}+\mathrm{MI}_{\mathrm{s}}{ }^{\mathrm{k}}
\end{aligned}
$$

$\mathrm{L}_{\mathrm{s}}$ : stator cyclic inductance; $\mathrm{L}_{\mathrm{r}}$ : Rotor cyclic inductance; M: cyclic mutual inductance

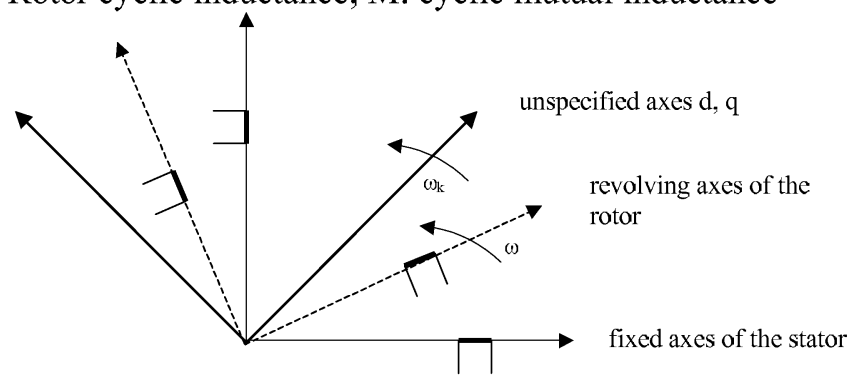

Fig. 7: Angle transformation

- Reference frame choice

In order to simplify the equations of the DFIG, the choice of the reference frame where equations (6) and (7) are projected, must be judicious. Indeed, the majority of the authors choose a reference frame related to the stator field. However, this choice is not the best in the considered application; the parameters to be controlled being the stator voltages, the choice of axes shifted $90^{\circ}$ behind on the vector of stator voltage $\left(\mathrm{V}_{\mathrm{sd}}=0\right.$ and $\left.\mathrm{V}_{\mathrm{sq}}=\mathrm{V}_{\mathrm{s}}\right)$ is much more advantageous [6]. It allows connecting the axis system directly to the frequency of the created network. Figure 8 illustrates this choice. 


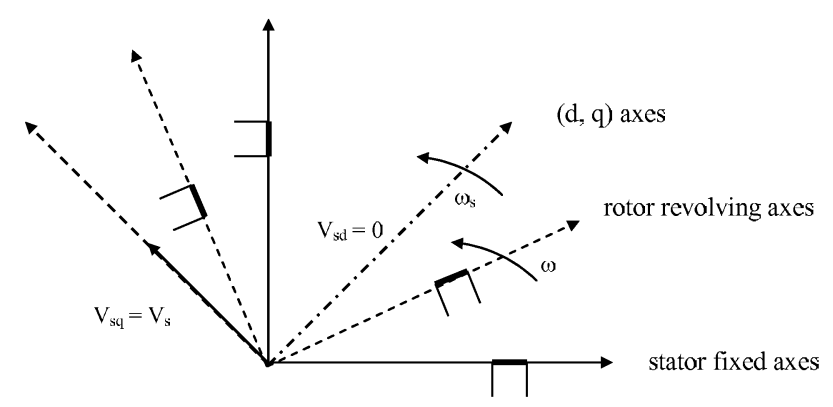

Figure 8: Reference frame choice $(\mathrm{d}, \mathrm{q})$

Under these conditions the generator equations are:

$$
\underline{\mathrm{V}}_{\mathrm{s}}=\mathrm{R}_{\mathrm{s}} \underline{\mathrm{I}}_{\mathrm{s}}+\frac{\mathrm{d} \underline{\Phi}_{\mathrm{s}}}{\mathrm{dt}}+\mathrm{j} \omega_{\mathrm{s}} \underline{\Phi}_{\mathrm{s}}
$$

$$
\underline{\mathrm{V}}_{\mathrm{r}}=\mathrm{R}_{\mathrm{r}} \underline{\mathrm{I}}_{\mathrm{r}}+\frac{\mathrm{d} \underline{\Phi}_{\mathrm{r}}}{\mathrm{dt}}+\mathrm{j} \omega_{\mathrm{r}} \underline{\Phi}_{\mathrm{r}}
$$

and

$$
\begin{aligned}
& \underline{\Phi}_{\mathrm{s}}=\mathrm{L}_{\mathrm{s}} \underline{\mathrm{I}}_{\mathrm{s}}+\mathrm{MI} \underline{\mathrm{I}}_{\mathrm{r}} \\
& \underline{\Phi}_{\mathrm{r}}=\mathrm{L}_{\mathrm{r}} \underline{\mathrm{I}}_{\mathrm{r}}+\mathrm{MI} \underline{\mathrm{I}}_{\mathrm{s}}
\end{aligned}
$$

By projecting these equations on the (d, q) axes system, the equations become:

$$
\begin{aligned}
& \mathrm{V}_{\mathrm{sd}}=\mathrm{R}_{\mathrm{s}} \mathrm{I}_{\mathrm{sd}}+\frac{\mathrm{d} \Phi_{\mathrm{sd}}}{\mathrm{dt}}-\omega_{\mathrm{s}} \Phi_{\mathrm{sq}} \\
& \mathrm{V}_{\mathrm{sq}}=\mathrm{R}_{\mathrm{s}} \mathrm{I}_{\mathrm{sq}}+\frac{\mathrm{d} \Phi_{\mathrm{sq}}}{\mathrm{dt}}+\omega_{\mathrm{s}} \Phi_{\mathrm{sd}} \\
& \mathrm{V}_{\mathrm{rd}}=\mathrm{R}_{\mathrm{r}} \mathrm{I}_{\mathrm{rd}}+\frac{\mathrm{d} \Phi_{\mathrm{rd}}}{\mathrm{dt}}-\omega_{\mathrm{r}} \Phi_{\mathrm{rq}} \\
& \mathrm{V}_{\mathrm{rq}}=\mathrm{R}_{\mathrm{r}} \mathrm{I}_{\mathrm{rq}}+\frac{\mathrm{d} \Phi_{\mathrm{rq}}}{\mathrm{dt}}+\omega_{\mathrm{r}} \Phi_{\mathrm{rd}}
\end{aligned}
$$

The equations of magnetic fluxes become:

$$
\left\{\begin{array}{l}
\Phi_{\mathrm{sd}}=\mathrm{L}_{\mathrm{s}} \mathrm{I}_{\mathrm{sd}}+\mathrm{M} \mathrm{I}_{\mathrm{rd}} \\
\Phi_{\mathrm{sq}}=\mathrm{L}_{\mathrm{s}} \mathrm{I}_{\mathrm{sq}}+\mathrm{M} \mathrm{I}_{\mathrm{rq}} \\
\Phi_{\mathrm{rd}}=\mathrm{L}_{\mathrm{r}} \mathrm{I}_{\mathrm{rd}}+\mathrm{M} \mathrm{I}_{\mathrm{sd}} \\
\Phi_{\mathrm{rq}}=\mathrm{L}_{\mathrm{r}} \mathrm{I}_{\mathrm{rq}}+\mathrm{M} \mathrm{I}_{\mathrm{sq}}
\end{array}\right.
$$

\section{$3 \quad$ Strategy of vector control}

Due to the multidisciplinary of the proposed approach, the adopted methodology for modelling was to structure the investigations fields by collaborations requiring specific competences (figure 9 hereafter).

The investigations of hydraulic specialists concentrate ther efforts on the characterization of the river and the turbine whereas electric engineering specialists are involved with the control of the stand alone generator ( $\mathrm{V}, \mathrm{f}$ regulation). 3 cases of operation are considered: hypo-synchronous operation, operation at synchronism speed and hyper-synchronous operation. Starting with magnetizing from the photovoltaic system needs a special and original approach.

The Matlab/Simulink simulation scheme proposed on figure 9, is broken up into 6 modules: from left on the right:

- characterization of the river,

- turbine characteristic (which is reproduced by a D.C current machine),

- generating hybridization on D.C bus through photovoltaic cells,

- control of the converter unit with the generator, 
- connection to the network,

- characteristics of a typical consumers load.

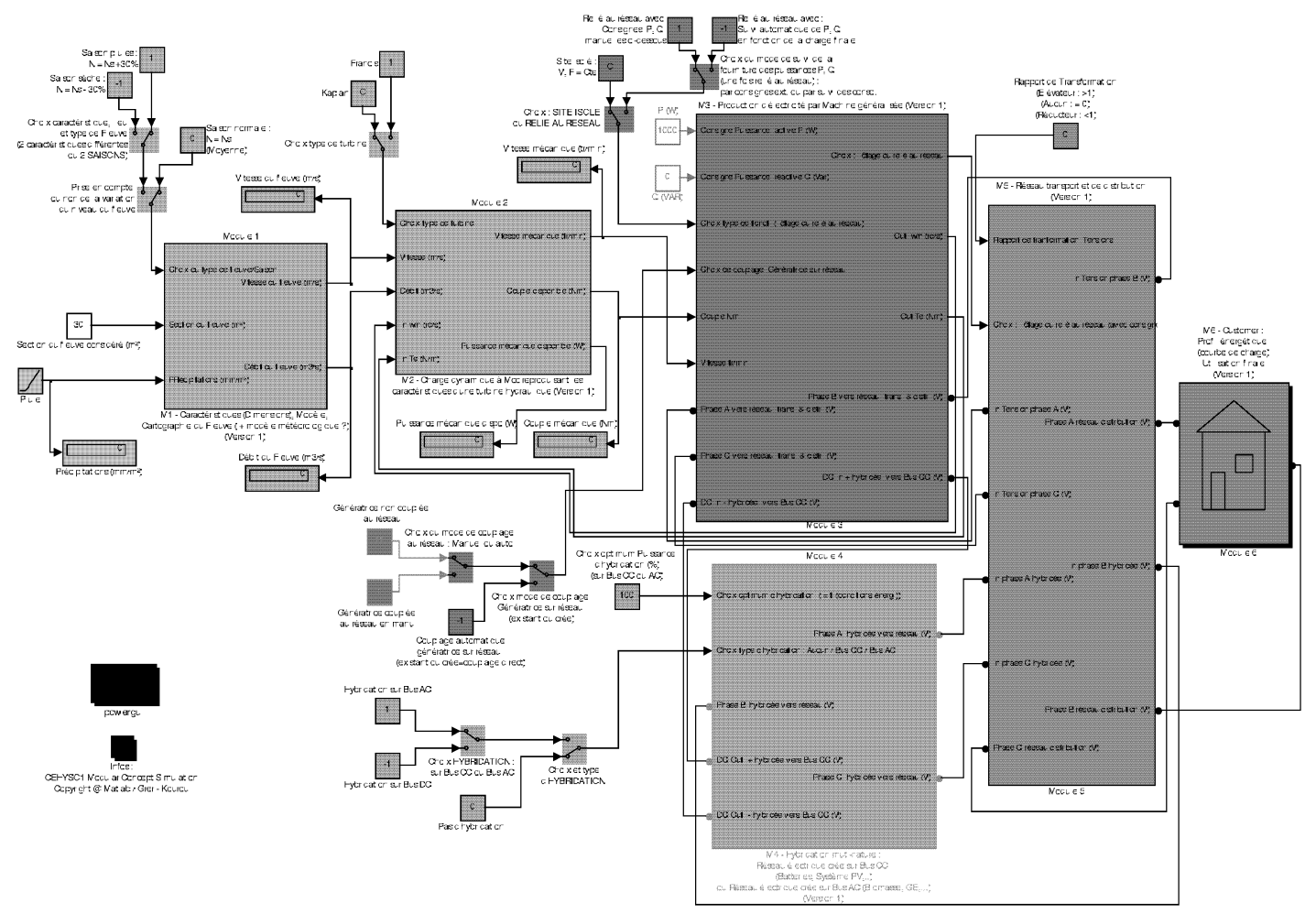

Figure 9: Modular strategy of suggested simulation

\section{Simulation results:}

Simulations (figure 10 and 11) have been carried out over 100 seconds (near the synchronism speed). We can observe the stability of the voltage and the frequency and this, in spite of transients reproducing a degraded operation.
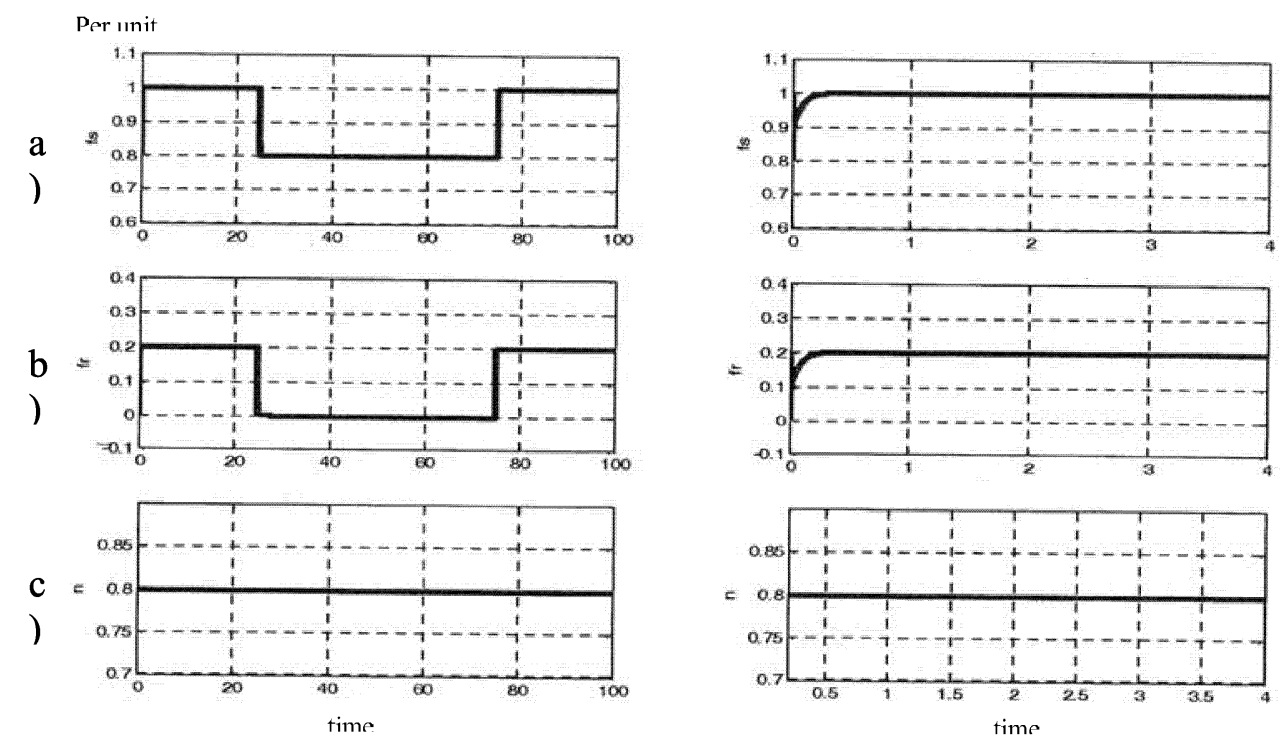

Figure 10: Disturbance on stability : a) stator frequency (fs), b) rotor frequency (frr), c) speed (n) 
Voltage between $\mathrm{b}$ and $\mathrm{c}$ phases

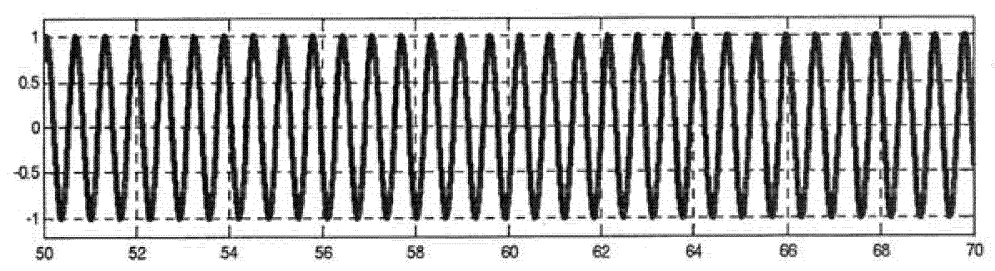

Figure 11: Stator Composed Voltages (between b, c phases : without load)

\section{Conclusion}

Thus, due to the large speed and flow variations in the French Guiana rivers, the Doubly Fed Induction Generator (DFIG), presents an original solution of compensation in acceptable proportions of the variability of the primary source and thus guarantees a good quality of the produced energy. Energy for magnetizing is furnished by photovoltaic cells through a DC Bus.

Simulations show that this type of system used in a Micro-Hydro Power Station is recommended for weak height falls. A complete $10 \mathrm{~kW}$ test bench controlled by a DSPACE system will allow validating the proposed concept. Stability and performances have to be carried on

Further developments will be the study of various control devices towards the interconnection and hybridization possibilities with other electricity power systems production with strong variability, (i.e. for isolated sites in equatorial environment and a mini network).

\section{Acknowledgments}

This multidisciplinary research subject appears in the $6^{\text {th }}$ measure of CPER-DocUp 2000-2006. Scientifically validated by the French Ministry for Research and Technology, this project is granted by European structural funds (FEDER), grants from the French Guiana Area, the Government and the University of the French West Indies and French Guiana.

\section{References}

1. Jacques Barret : "Atlas 2004 de la Guyane" - Editions PUG

2. Water Power Industries «Energy from quietly flowing rivers », p7, CADDET Info Point, Issue $1 / 4$, March 2004

3. SERT «Etude de l'électrification du campement touristique de Saut Sonnelle », 24p, Juillet 1999, Rapport commandé par l'ADEME Guyane

4. H.Godfroid, A.Mirzaian, D.Ramuz: 'Machine synchrone pour procédés exigeants', Revue Internationale de Génie électrique, pp9-35

5. F.Poitiers, M.Machmoum, R.LeDoeuff : 'Simulation of a Wind Energy Conversion System Based on a Doubly Fed Induction Generator', EPE 2003, CD, pp1-10

6. S.Tnani, S.Diop, A.Berthon, JM.Kauffmann: 'A generalized Model for Double Fed Induction Machines', IASTED 1995

7. F.Khatounian, E.Monmasson, F.Berthereau, E.Delaleau, JP Louis : 'Analyse et commande d'un système de génération électrique pour réseau de bord d'avion', EF 2003 - Supélec, 9, 10 Déc. 2003, CD

8. D.Lecocq, P.Lataire, W.Wyjmeersch: 'The Double Fed Induction Motor both Stator and Rotor Voltages Controlled by Cyclo-converters', European Power Electronics Journal, Vol 1, Oct 1991, pp 103-112

9. S. Muller, M. Deicke, R.W. De Doncker : 'Doubly-Fed Induction Generators Systems for Wind Turbines, IEEE Industry Applications Magazine, May, June 2000 
10. B. Robyns, Y. Pankow, L. Leclercq, B. François : 'Equivalent Continuous Dynamic Model of Renewable Energy Systems', 7th International Conference on Modeling and Simulation of Electric Machines, Converters and Systems : ELECTRIMACS 2002, Canada, Montreal, CD

11. Ludovic Leclereq, Aymeric Ansel, Benoït Robyns : "Autonomous high power variable speed wind generator system" : EPE 2003 - Toulouse CD-Rom

12. O.Gergaud, G.Robin, B.Multon, H.Ben Ahmed : "Energy modeling of a lead acid battery within hybrid Wind / Photovoltaic systems" : EPE 2003 - Toulouse CD-Rom

13. Christian R Kelber, Walter Schumacher : "Active damping of flux oscillations in doubly-fed AC machines using dynamic variation of the system's structure" : EPE 2001 - Graz CD-Rom 